\title{
Tax Policy and Foreign Direct Investment: Empirical Evidence from Mauritius
}

\author{
Sharvesh Digumber ${ }^{1}$, Hemavadi Soondram ${ }^{1}$, Bhavish Jugurnath ${ }^{1}$ \\ ${ }^{1}$ Department of Accounting and Finance, Faculty of Law and Management, University of Mauritius, Réduit, \\ Mauritius \\ Correspondence: Bhavish Jugurnath, Lecturer, Department of Accounting and Finance, Faculty of Law and \\ Management, University of Mauritius, Réduit, Mauritius. E-mail: b.jugurnath@uom.ac.mu
}

Received: November 30, 2016

Accepted: January 12, $2017 \quad$ Online Published: February 8, 2017

doi:10.5539/ibr.v10n3p42

URL: http://dx.doi.org/10.5539/ibr.v10n3p42

\begin{abstract}
This study demonstrates, through the use both qualitative and quantitative data, that there are several factors determining Foreign Direct Investment flows between two countries. A total of 180 accountants were surveyed in this study, whereby the majority of respondents agreed that Capital Gains Tax is an important factor determining FDI flow within a tax treaty but is not the only significant factor. The study also used regression analysis through a gravity equation to confirm the survey's conclusion. Using Mauritius and a host of its tax treaty partners as proxies, it was found that Gross Domestic Product per capita, Capital Gains Tax, common language and distance were major factors affecting Foreign Direct Investment flow in a bilateral tax treaty. This study gives a good insight on the reasons why foreign investors use the Mauritian tax treaty network as a platform for investment. The main rationale for such investments was attributed to Mauritius offering a $0 \%$ Capital Gains Tax rate and being a low tax jurisdiction. However, this study sheds new light on this reasoning and provides evidence that investment does not depend solely on Capital Gains Tax levy but also a host of other important factors.
\end{abstract}

Keywords: CGT, determinants of FDI, FDI, gravity model, Mauritius

\section{Introduction}

There are various factors affecting FDI flows between countries and various benefits in bringing in FDI into a country, such as increased competition, training and upgrading human resources and bringing in technology. Small economies like Mauritius receive criticism about attracting 'treaty abusers' while bringing in FDI and such a scenario motivates countries to proposing the introduction of a CGT to counter misuse of tax treaties. This study determines the factors affecting FDI when it comes to tax treaties. It tests whether CGT is the main determinant of FDI flowing to and from Mauritius or if it is one of the major determinants. If it is found that CGT is the main determinant, it can lead to suggestions that Mauritius in fact attracts treaty abuse. Moreover, it is known that CGT might not be the only cause of FDI movements through the Mauritian route. There is a possibility that CGT does not significantly affect FDI flows. This is why it is important to test several other possible determinants and see if they significantly affect FDI.

The main aim of this study is to find out some of the possible main causes of FDI flows through the Mauritian route when it concerns trading with tax treaty partners. This study also aims to see if CGT is the main or one of the main determinants of FDI. Being regarded as a tool of treaty abuse when CGT is not taxed, it is important to see if the inexistence of CGT in a tax treaty really affects significantly FDI. This will then lead to a possible conclusion about whether the Mauritian route can be used as a treaty abuse destination. Finally, this study aims to provide valuable insight about perceptions of stakeholders from the Mauritian accounting and finance sector on the newly introduced BEPS. This new measure is likely to become imminent in the near future and is supposed to act as a detriment to invest in a country for treaty abusing purposes.

\section{Literature Review}

\subsection{Empirical Evidence}

Theoretical studies show that there are numerous factors which affect FDI flow in a country. In recent years, we have seen many bilateral tax treaties put in place for the various benefits they contribute to the nations. New 
insights in the field have captured the attention of researchers. Much research have been done to measure the different determinants of FDI. However, different types of FDI exist- inflow, outflow, firm level, industry level and national level. A self-contained general theory cannot be put in practice and such cases have been questioned by the likes of Agarwal (1980), Parry (1985), Itaki (1991). Tax revenue provides a main source of income to governments but tax benefits provide a competitive edge over resource allocation and distribution. Hence, theoretically tax treaties have an impact on the economic progress of any nation. Theoretical evidence also suggests that keeping CGT low will increase the level of FDI. Past literature suggest that small open economies should not tax capital gains as it will be against their favour. (Diamond \& Mirrlees, 1971) showed, through a one consumer economy, that a small open economy will attain an efficient production rate by offering a low tax scheme or not tax at all. A study of Wilson (1991) showed that tax base relocation is proportionately more important for small economies and hence, will have a higher incentive to keep CGT, whereby they could create a "race to the bottom". Gordon (1990) explained that in a world getting more and more connected through globalisation, it is now very difficult for governments to set capital controls, whereby investors are disallowed from investing abroad. Investors, being rational in nature will choose to invest in jurisdictions offering the most favourable tax schemes. The author follows the theory that with the increasing openness of the European Community, and the world in general, worldwide capital gains taxation shall be as low as $0 \%$.( Bénassy-Quéré, Fontagne \& Lahreche-Revil, 2003) also backed this idea by stating that global competition increases will cause a growing pressure on tax policies and increases in taxes (like CGT) in one country will give an incentive for investors to shift their investment from that country to another. (Razin \& Sadka, 2007) explained that to tap into the FDI inflows and earn a profit out of it, a country can use two methods; impose a minimum sales price on domestic firms or impose a CGT on FDI investors. The profit will then be distributed between the host country and the investors. (Eicher, Helfman \& Lenkoski, 2011) found that higher taxes and financial risk increase FDI outflows from the host country, while lower taxes and financial risk have a positive effect on investment inflows.

(Artige \& Nicolini, 2005) have seen in their study that per capita GDP an important FDI determinant, using econometric studies. This is applicable for horizontal FDI, where firms with several plants will perform the same activities in various countries. Jordaan (2004) suggests that FDI will flow to countries with bigger markets where people have higher purchasing power. Firms will hence achieve higher return on investment. In fact, (Brooks, Fan \& Sumulong, 2003); (Crespo \& Fontoura, 2007) all reach consensus that there is a mutual relationship between FDI and GDP per capita, where FDI provides capital, technology and foreign exchange to the recipient country. (Portes \& Rey, 1999) have found that there is a strong negative relationship between FDI and distance. Gravity models used in past literature have all included the distance factor to determine trade patterns. Moreover, the 'non-diminishing' effect of distance over trade provides a fixed variable to be studied over time. Countries have a better relationship when they share common attributes like culture, language, shared festivals and historical ties. (Kim, Liu, Kim-Lee, Brown \& Leblang, 2013) used Philippines (ex-Spanish colony) and its 2010 agreement with Spain to re-introduce Spanish into the educational curriculum. They linked the incident with the visit of Spanish Business Executives to explore investment ventures. The authors state that many more countries are using such tactics to attract FDI. The latter study reviewed literature which suggest that "States with the same languages or legal structures will be more likely to engage in economic exchange. Eicher et al. (2011) studied the determinants of FDI and explained that there is little consensus on the main determinants of FDI flows. They used the Bayesian Model Averaging and agree that there is a consensus that FDI increase causes an increase in economic growth. Morisset (2003) used data from 58 countries showed through utility function that when a country highly invests in ease of doing business strategies, whereby the investment climate becomes favourable, FDI is likely that to be influenced considerably. (Dimitropoulou, Burke \& MC Cann, 2007) agrees on this by stating a country which has industrial promotion agencies to promote segment of specialisation will have a positive impact on FDI However, (Wheeler \& Modi, 1992) shows that bureaucracy risk does not deter investments made by MNCs in a country and hence, ease of doing business strategies will have little impact of FDI flow.

Eicher et al. (2011) found that the creation of government policies such as providing low tax rates boosted FDI flow. This conclusion contradicts (Wheeler \& Modi's, 1992) findings that FDI flow is not affected significantly by a corporate tax rate. Authors have also linked FDI flow with risk level, particularly political risk. (Cieslik \& Ryan, 2004) and Blonigen (2005) show that high political risk level tends to decrease FDI flows. Blonigen (2005) also shows that proper government institutions and appropriate legal protection (such as protection of intellectual property rights) are very important tools to promote FDI. (Wheeler \& Modi, 1992) criticise this finding by concluding that socio-political risk did not have a significant impact on FDI. Various studies have tried to find a correlation between the level of corruption and FDI. (Wei \& Smarzynsk, 2010) found that a foreign investor's choice will depend on the level of corruption in a host country. Using U.S. investors' data, it was found from survey analysis that American investors were rather reluctant to invest in foreign countries marked as corrupt. 
(Rios-Morales \& Brennan, 2007) found a positive direct correlation between the level of risk and corruption level, hence decreasing the investment level. However, (Wheeler \& Modi, 1992) also studied corruption in U.S. and FDI and found that corruption was not a major deterrent on investment. (Kolstad \& Villanger, 2004) also shows that despite some countries show some degree of corruption, FDI keeps flowing. Studies have also linked FDI to quality of human capital accompanied by low labour cost. (Kinoshita \& Campos, 1997) found that skilled labour force had the ability to attract multinationals within a country. (Cheng \& Kwan, 2000) also found that a highly productive workforce had positive effects on attracting MNCs. (Noorbakhsh, Palom \&Youssef, 2001) found that a country offering quality labour force has a higher potential in attracting FDI. Such results have been contradicted by (Groh \& Wich, 2009) who found that the level of investment does not depend on the quality and value of labour force but rather is influenced by location and sector.

Braunschweig (2014) used the gravity model to determine the relationship between the level of trade and the signing of a DTAA. His model presented the trade flows between two countries as directly and proportionately related to their respective sizes and negatively proportional to their geographical distance. Hines (1998) analysed the importance of providing tax benefits in a tax treaty and its relative impact on FDI, by using figures from Japanese, American and U.K treaties. Hines used the terminology "Tax sparing" which he defined as "a practice designed to promote the effectiveness of local tax incentives for foreign investment' and 'the practice by which capital exporting countries amend their taxation of foreign source income to allow firms to retain the advantages of tax reductions provided by host countries." For example, in the India-Mauritius tax treaty prior to 2013, India had given the rights to capital gains taxation to Mauritius, which subsequently tax capital gains at a rate of $0 \%$. Developing countries are usually willing to provide tax incentives such as low or no CGT to promote and attract FDI and hereby boost economic growth. Many developed countries which have tax treaties with such developing countries provide 'tax sparing' facilities, which will help investing firms to ask due on foreign tax credits against home country tax liabilities. Such liabilities would otherwise have been paid external countries without the use of special clauses in treaties. Hines (1998) used the case of Japan, which uses 'tax sparing' methods in several of its treaties with developing countries, and the case of US which prohibits the use of any tax incentive methods in its treaties. The author concludes that such tax incentives really have a significant impact on FDI. Moreover, Japanese firms prefer to invest in countries with which it has preferential treaty agreements such as not taxing capital gains. It was also found that Japanese treaty partner countries prefer to give Japanese firms (instead of American firms) special tax breaks. The findings clearly show that tax systems and schemes influence the volume and location of FDI. Bénassy-Quéré et al. (2003) also studied the impact of corporate taxes on FDI. The latter used econometrics to measure bilateral FDI flows across 11 OECD countries over 1984-2000 and noted that a high level of corporation tax, including CGT is a huge deterrent of investment. The authors conclude that though there are many determinants of FDI, like market potentials, taxes play a very important role in attracting FDI flows. However, contrary to the empirical evidence, this study showed that despite large amount of corporation tax is a major deterrent of FDI, low tax rates in host countries do not contribute significantly to attract investment.

\subsection{Capital Gains Taxation in Treaties}

This study puts a lot of emphasis on CGT being the main determinant of FDI for the Mauritian tax treaty network. DTA treaties are based on international tax laws. This study includes the effect of CGT on Tax Treaties and the final impact on FDI. Provisions on FDI are discussed in Article 13 of the OECD and UN Models. In such models, basic elements regarding capital gains are explained. For example, capital gains from 'alienation' of properties can be taxed in the Country of Residence (COR). Alienation has been explained in the Mauritius-Singapore tax treaty as the "sale, exchange, transfer, or relinquishment of property or extinguishment of any rights therein or the compulsory acquisition thereof under any law in force in the respective Contracting States." COR refers to the seller's country of residence. The Country of Source (COS) is given non-exclusive rights to tax immovable property, business assets forming part of Permanent Establishments (PE), ownership interest in entities that derive value principally from immovable property, and shares forming significant participation in a resident company.

CGT is taxed based on legislations found in Article 13 of a tax treaty. The Mauritius-India and Mauritius-Singapore tax Article 13 relating to tax treaty will be used as reference. Amendments to Article 13 tend to go for a form of imposition of CGT on trade between two nations which previously did not tax CGT at all. Recent examples come from the Mauritius-China 2007 amendment, Mauritius-South Africa 2015 amendment and the Mauritius-India 2015 agreement. Sornarajah (2010) defined treaty shopping as "a technique which nationals of a state use in order to protect their investments from interferences by their own states.' Under such a situation, an investor will transfer its investment in a country B and the re-transfer such investments into his own country. The rationale behind this move is that it allows the investor to gain from positive benefits given by the 
investor's government to foreign investors as well as a form of protection (e.g. diplomatic protections and protection of investment treaties). The main conflict which arises is that it becomes difficult to separate such inflow of capital of local investors to FDI inflows. An (2011) showed that an increase in corporate income tax, which took effect in 2008, reduced the preferential treatment offered by China to its foreign investors. Investments from Hong Kong, Macau and Taiwan, countries which were suspected to welcome round tripping from China, significantly decreased. The author concluded that an increase in corporate income tax reduced investment into China linked to round tripping.

There seems to be a co-incidence between the recent ratification of the Mauritius-India, Mauritius -South Africa tax treaties in 2013 and the issue of OECD report on BEPS in the same year. Sithanen (2015) argues that modifications to the Articles 13 of the India-Mauritius treaty will have the same effect as the Mauritius-South Africa treaty, whereby investment will wither out. Ohno (2010) has conducted an analysis on the Japanese network of tax treaties. The author found that newly concluded treaties had statistically significant long term positive impact on FDI while revised treaties did not have statistically significant impact on FDI. (Barthel, Busse \& Neumayer 2009) used the estimation model and GMM for large dyadic panel data and showed that double tax treaties have significant and positive effect on FDI.

\section{Research Methodology}

Most of the questions available in the questionnaire were set based on the empirical and theoretical evidence found in the literature review. A total sample of 180 questionnaires was sent to the firms. 87 fully answered questionnaire was received. The population under consideration is represented by professional accountants having an ACCA or ACA qualification. The reason behind this representation is that such a population already have theoretical and technical background knowledge on the topic. Big 4 organisations (including EY,KPMG, PwC \& Deloitte) were mostly considered because they are behind major accounting and tax advances and their technical knowledge have greatly contributed to this paper. Only one member of the population is from South African origin; the remaining population is Mauritian, working in Port-Louis, Ebene and Rose-Hill. We chose a sample instead of the whole population because of cost and efficiency limitation. After removing outliers, a sample of 70 questionnaires were deemed fit for the study.

\subsection{Gravity Model}

Net FDI flows is the dependent variable while independent variables used are GDP per Capita, Corruption, Common Language and CGT.

\begin{tabular}{lll}
\hline & Explanation & SYMBOL \\
\hline Net FDI & $\begin{array}{l}\text { Net FDI represents the total of FDI inflow and FDI outflow. NET FDI is } \\
\text { represented in terms of USD }\end{array}$ & FDI
\end{tabular}

\section{Per Capita GDP}

Distance
Common
Language
CGT

Per Capita GDP is the GDP in USD per number of people on the country

Distance per 1000 of $\mathrm{Km}$ shared between two countries

Common official language shared between two countries

Does a form of Capital Gains Tax exist between two trading countries or are there any official news that links to the probability that CGT will be imposed.

Major literature reviews correlating FDI and determining factors have used the Gravity Equation. This gravitational model was first used for social science studies in the 1960s by Tinbergen and has later on been found to be useful in studies involving international trade. This model has been found to be useful in studying FDI and its relative determinants. In trade-theory, the gravity equation in its most basic and frequently used form is specified as:

$$
\ln X_{i j}=\beta_{0}+\beta_{1} \ln Y_{i}+\beta_{2} \ln Y_{j}+\beta_{3} \ln D_{i j}+\beta_{4} \ln F_{i j}+\mu_{i j}
$$

Where $X_{i j}$ is the trade flow between country $\mathrm{i}$, which is the host and country $\mathrm{j}$ which is home. $Y$ is the GDP of the two countries, measured at a prevailing currency denomination. $D_{i j}$ is the distance which separates both countries. $F_{i j}$ represents dummy factors or other variables which may affect trade between the two countries.

This study will derive its own formula based on factors believed important, taking evidence from the literature. It is represented as follows: 


$$
\ln F D I_{i j t}=\beta_{0}+\beta_{1} \ln P C_{i t}+\beta_{2} \ln P C_{j t}+\beta_{4} \ln D I S_{i j}+\beta_{5} \ln L a n g_{i j}+\beta_{6} \ln C G T_{i j}+\mu_{i j t}
$$

Where:

$F D I_{i j t}$ : Net Foreign Direct Investment from country, relevant years from 2010-2014

$\mathrm{j}$ (home) to country I (host)

Source: http://www.bom.mu/pdf/statistics/Balance_of_Payments/FDIQ22015.pdf

$\mathrm{PC}_{\text {it }}$ : Per capita GDP of country $i$ at time $t$ in MUR

$\mathrm{PC}_{\mathrm{jt}}$ : Per capita GDP of country $\mathrm{j}$ at time $\mathrm{t}$ in MUR

Source: world Bank data

DIS $_{\mathrm{ij}}$ : The Distance $(\mathrm{Km})$ between country I and J

\section{Source: Google Maps}

Lang $_{\mathrm{ij}}$ : The dummy variable which takes into value of 1 if there is common official language, else 0

Source : https://www.cia.gov/library/publications/the-world-factbook/fields/2098.html

$\boldsymbol{\beta}_{\mathbf{i}}(\mathrm{i}=1$ to 6 ) is the variable regression coefficient computing the link between Net FDI and the independent variables

\section{$\mu_{i j t}:$ Error term}

The formula has been chosen based on the empirical research on this area. The Gravity model suggests that bilateral Foreign Investments between 2 countries are positively related to their relative economic sizes and negatively related to their population sizes and distance. Many literatures have given importance to GDP per capita, taxes, language barrier and distance factor as major determinants of FDI between countries. Hence, this study will use the Gravity model and will include the relative importance of CGT, GDP per capita, and distance as determinants of FDI.

GDP per Capita (Home and host country): This variable is always positive and significant. It is a means to show a country's economic growth, whereby high income countries have a bigger share of international investment flows. GDP per Capita is measured in MUR at year end.

Distance: This variable usually has an adverse effect on trade and investment. It appears in the equation in a negative and significant sign.

Common Language: Studies have found that countries sharing at least a common language will have more shared investors.

CGT: A form of capital gains tax has negative and significant impact on FDI. Even a news of bringing in a form of CGT will cause a drop in CGT.

This study will use India, Belgium China and South Africa as data for analysis. The main reason behind this is the drastic change in level of FDI throughout the 5 years between 2010 and 2015. China, South Africa and India was especially used due to the recent amendments in the Article 13 of the respective treaties with the aforementioned countries. The time series includes the 5 years 2010-2015 due to easy availability of data through reliable sources.

Regression Model: The appropriate regression model had to be chosen among Ordinary Least Squares (OLS), Fixed Effects Model (FEM), Random Effects Model (REM) and Generalized Method of Moments (GMM). Tests are carried out to find the appropriate model. Hausman test is used to compare between REM and FEM by calculating the p-value (Prob>chi2).

Under Ho: REM is consistent and efficient

\section{H1: FEM is consistent and efficient}

Breusch-Pagan Lagrangian multiplier test is used to distinguish between REM and OLS.

Under Ho: REM is consistent and efficient

H1: OLS is consistent and efficient

It is noted that both Hausman test and Breusch-Pagan Lagrangian use a 5\% significance level.

\subsection{Formulation of Hypothesis}

Hypothesis 1: Per Capita GDP of home country has positive and significant statistical impact on FDI. 
H1: Per capita GDP of home country has a positive significant statistical impact on FDI

Hypothesis 1.1: Per Capita GDP of host country has positive and significant statistical impact on FDI.

H1: Per capita GDP of host country has a positive significant statistical impact on FDI

(Artige \&Nicolini, 2005)

Hypothesis 2: Introducing CGT or news of future imposition of CGT has positive and significant statistical impact on FDI

H1: Introducing CGT or news of future imposition of CGT has positive and significant statistical impact on FDI

Hypothesis 3: A shared common language between host and home country has significant and positive impact on FDI.

Hypothesis 4: Distance between Mauritius and double-tax treaty partner has significant and negative impact on FDI.

This study uses the Breusch-Pagan/Cook-Weisberg test to test the assumption of homoscedasticity. In contrary to homoscedasticity, heteroscedasticity is an undesired situation whereby the variance of the error terms will fluctuate across the independent variables. This will impact on the result as despite the variables and test data remaining unbiased, it will cause the regression model to be inefficient. The hypothesis to be tested shall be:

H0: Heteroscedasticity is absent

H1: Heteroscedasticity is present

Breusch-Pagan/Cook-Weisberg test uses a 5\% significance level.

\subsection{Autocorrelation}

This test was first presented by Wooldridge (2002) for panel data models. Errors should be independent and uncorrelated; autocorrelation test is used to confirm this assumption. The hypothesis to be tested is:

H0: No first order autocorrelation

H1: There exist a first order autocorrelation

Again, the test used a 5\% significance level.

\subsection{Random Effect Model (REM)}

This model is vital to this current study. It allows the data generated for the purpose of this study to be generalised to a limited range of scenarios and to be extrapolated to the sample population. The different variables presented in the gravity model differ greatly in terms of values and cannot be related without a given model. REM caters for this problem while assuming that the error terms are uncorrelated while being independent.

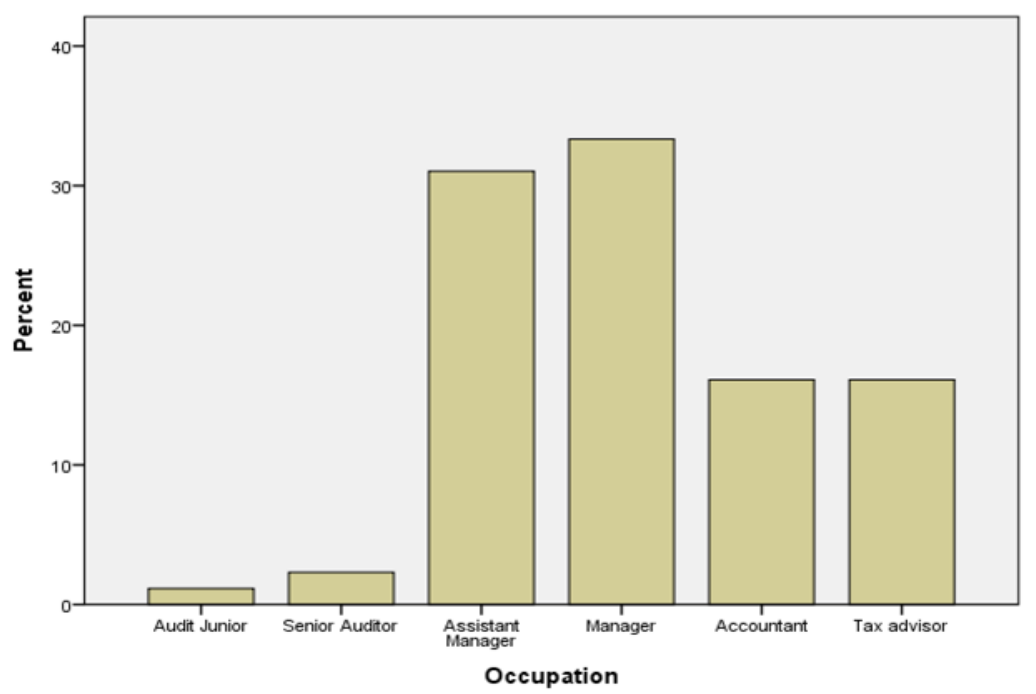

Figure 1. Respondents' occupation 


\section{Results}

Figure 1 shows that $30.3 \%$ of respondents are assistant managers and $32.3 \%$ are managers. All of the respondents work in the auditing/tax/finance sector.

Figure 2 shows that $54 \%$ of the population had more than 5 years of working experience, 5-9 years and 10-14 years of working experience represented $23 \%$ of the population. This gives insight about the quality of the questionnaire response; more experienced respondents are expected to give more valid and consistent answers.

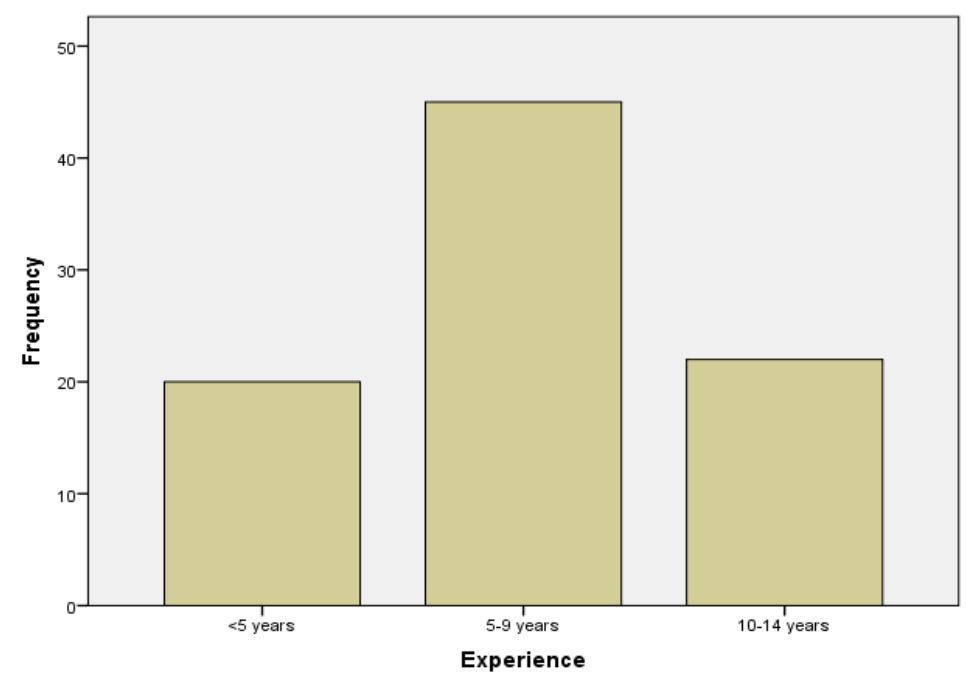

Figure 2. Respondents' work experience

Figure 2 shows that $51.7 \%$ of the have between 5 and 9 years of experience and are currently working in the accounting or finance sector. $23 \%$ of the respondents have less than 5 years of experience while $25.3 \%$ represent respondents having 10-14 years of experience.

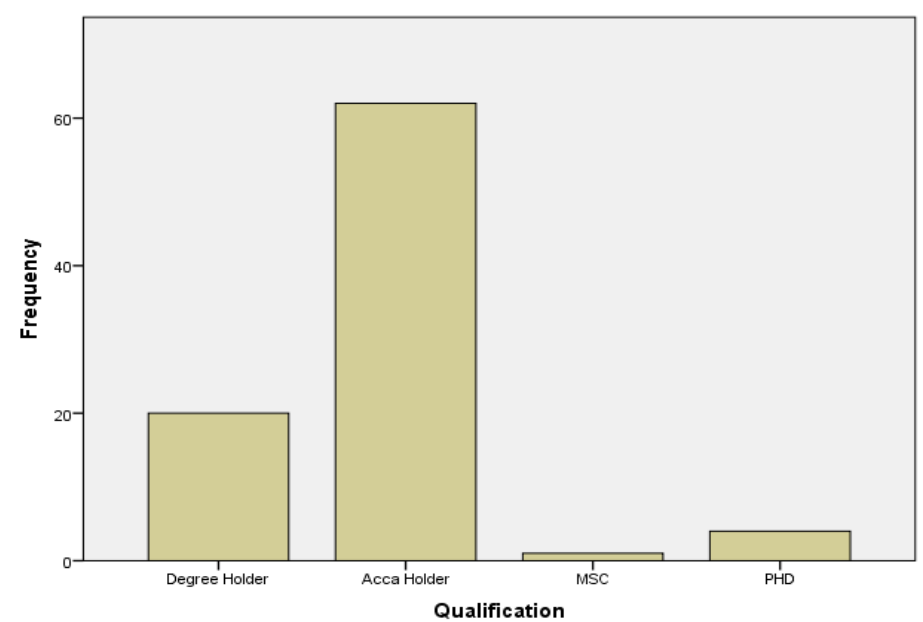

Figure 3. Respondents' qualification

$72.3 \%$ of the respondents hold an ACCA qualification while $23 \%$ hold a university degree. $1.1 \%$ hold an MSc while $4.6 \%$ hold a $\mathrm{PhD}$.

\section{BEPS as a Factor Affecting FDI}

BEPS is a newly introduced solution to eradicate treaty abuses and is perceived to be a new determinant of FDI. 


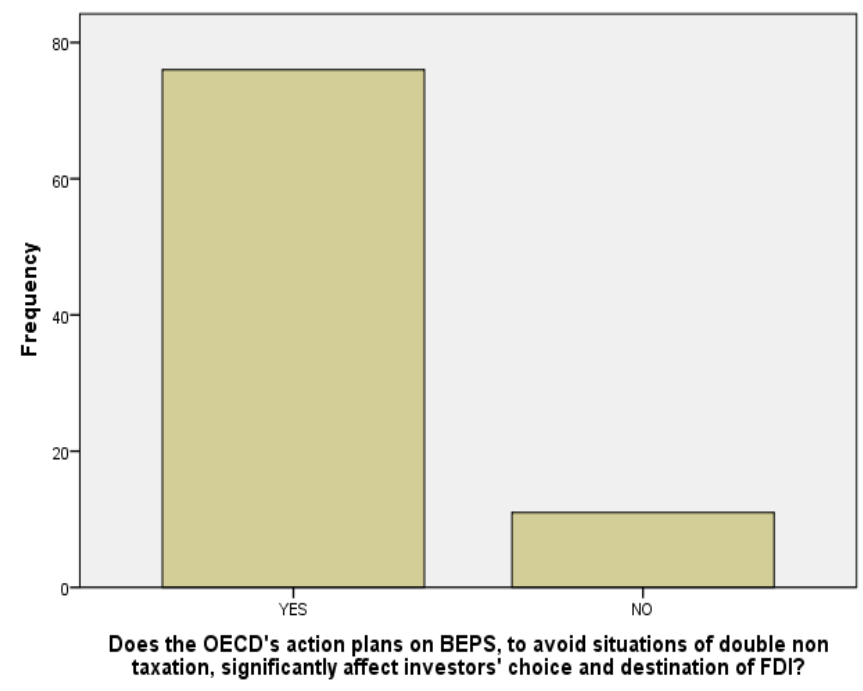

Figure 4. BEPS and FDI

Respondents were asked whether the OECD's action plans on BEPS, to avoid situations of double non taxation, significantly affect investors' choice and destination of FDI. $87.4 \%$ of the sample population have agreed that BEPS strategies will surely affect the current FDI patterns.

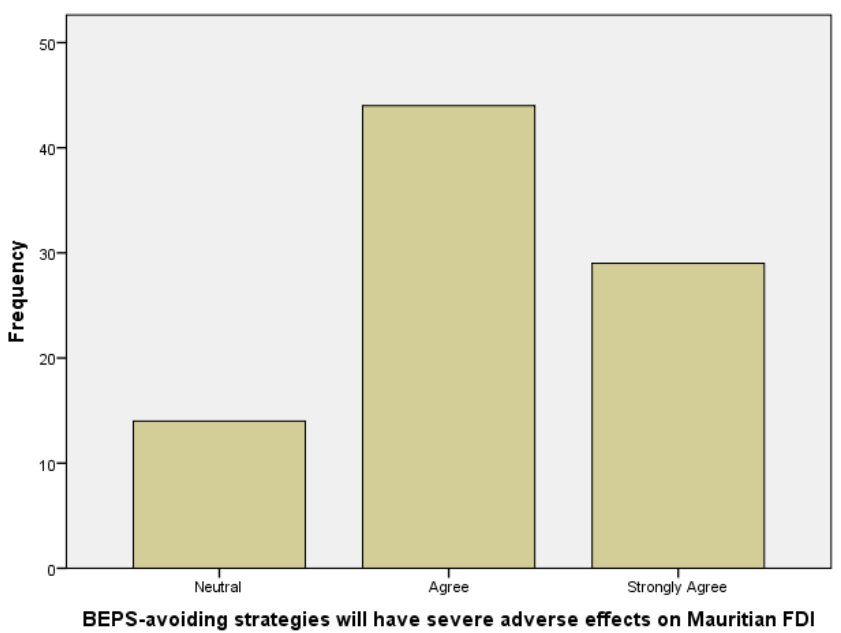

Figure 5. Opinions about BEPS effects in Mauritius

The idea that BEPS will affect Mauritian FDI significantly is shared among the population. $16.1 \%$ were neutral about the question but 50.6\% agreed that BEPS avoiding strategies will have severe on Mauritian FDI and 33.3\% strongly agreed on this statement. This is a possible representation of the growing concern of local investors and stakeholders of the accounting and finance sector about this new determinant of FDI.

\section{Factors affecting FDI}

The questionnaire provided the respondent to a list of factors which could potentially affect FDI. The mean score and standard deviation is recorded as:

Table 1. Factors affecting FDI

\begin{tabular}{|c|c|c|c|c|c|}
\hline & $\begin{array}{l}\text { Political risks in Mauritius } \\
\text { or in its treaty partner } \\
\text { countries tend to decrease } \\
\text { FDI flow }\end{array}$ & $\begin{array}{l}\text { Availability of legal } \\
\text { protections (such as protection } \\
\text { of IPR) is an important } \\
\text { determinant of FDI }\end{array}$ & $\begin{array}{l}\text { Factors like exchange rate } \\
\text { fluctuations and inflation } \\
\text { affect FDI flow within a tax } \\
\text { treaty }\end{array}$ & $\begin{array}{l}\text { The level of corruption } \\
\text { is a major deterrent on } \\
\text { investing in a country }\end{array}$ & $\begin{array}{l}\text { Human capital quality } \\
\text { and cost have a direct } \\
\text { impact on investing in a } \\
\text { country }\end{array}$ \\
\hline Mean & 4.2759 & 4.2644 & 3.6782 & 4.2644 & 4.1149 \\
\hline $\mathrm{N}$ & 87 & 87 & 87 & 87 & 87 \\
\hline $\begin{array}{l}\text { Std. } \\
\text { Deviation }\end{array}$ & .47470 & .63721 & .99410 & .63721 & .65460 \\
\hline
\end{tabular}


All of the above-mentioned factors: political risks, trade protections, exchange rate fluctuations and inflation, corruption and cost \& quality of human capital are deemed to be determinants of FDI by the population. Most respondents agree on political risk playing an important role on net FDI, having a low standard deviation of 0.47. The majority of respondents also agreed on the roles of the other factors, being determinants of FDI. Respondents' answers were quite spread when it concerned exchange rate fluctuations and inflation. This might be due to the fact that such factors are less easy to control through economic decisions. The questionnaire has used the case of Mauritius-India and Mauritius-South Africa treaties to ask respondents if the main reason for using this trading route was because the non-levy of CGT.

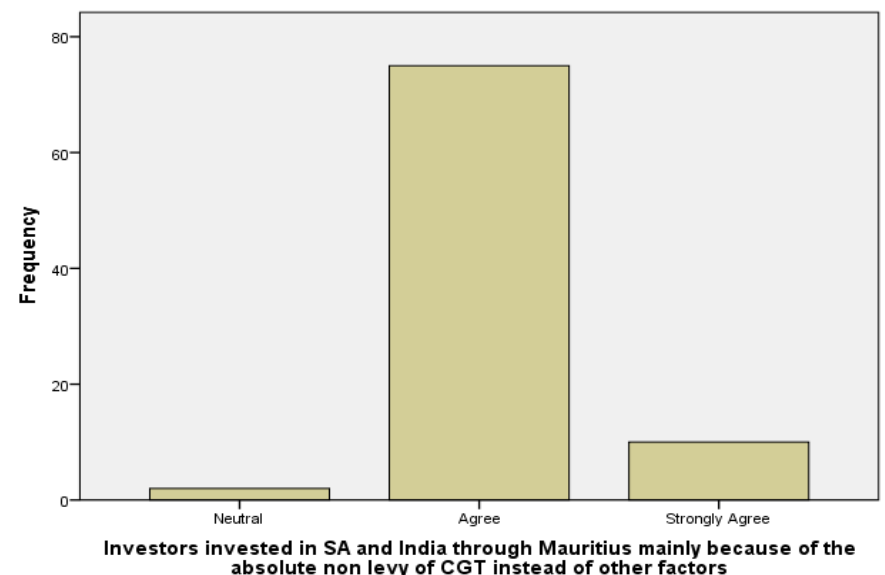

Figure 6. Opinions on SA/INDIA-Mauritius FDI flow

$86.2 \%$ of the respondents agree on the fact that the non-levy of CGT is a main attraction when it comes to the Mauritian trading route with South Africa and India.

\section{Correlations}

Table 2. Correlations

\begin{tabular}{|c|c|c|c|}
\hline & & $\begin{array}{l}\text { Political risks, legal protections } \\
\text { exchange rate fluctuations, inflation, } \\
\text { corruption and human capital quality } \\
\text { are determinants of FDI }\end{array}$ & $\begin{array}{l}\text { There are more } \\
\text { than one factors } \\
\text { affecting FDI in a } \\
\text { country }\end{array}$ \\
\hline $\begin{array}{l}\text { Political risks, legal } \\
\text { protections exchange rate } \\
\text { fluctuations, inflation, } \\
\text { corruption and human capital } \\
\text { quality are determinants of } \\
\text { FDI }\end{array}$ & $\begin{array}{l}\text { Pearson Correlation } \\
\text { Sig. (2 tailed) } \\
\text { N }\end{array}$ & ( & $\begin{array}{l}.224^{*} \\
.037 \\
87\end{array}$ \\
\hline $\begin{array}{l}\text { There are more than one } \\
\text { factors affecting FDI in a } \\
\text { country }\end{array}$ & $\begin{array}{l}\text { Pearson Correlation } \\
\text { Sig. (2 tailed) } \\
\mathrm{N}\end{array}$ & $\begin{array}{l}.224 * \\
.037 \\
87\end{array}$ & $\begin{array}{l}1 \\
87\end{array}$ \\
\hline
\end{tabular}

Source: Author's computation using SPSS 23

*. Correlation is significant at $5 \%$ level ( 2 tailed)

Correlation coefficient has been used to determine the relationship between various possible determinants of FDI (refer to questionnaire Section 1 Q (i), (ii), (iii), (iv), (v)) and respondents perception about having multiple determinants of FDI (refer to Section 2 Q (iv)). The result (see table 2) shows a positive (.224) and significant relationship (0.037 at 5\% sig. level) between respondents believing that there are more than one factors affecting FDI and their perceptions about the aforementioned factors being plausible determinants of FDI. This gives an indication that respondents believe there might be several other factors affecting FDI.

Table 3 shows the relationship between the perception of respondents on whether there is a form of treaty abuse in Mauritian tax treaties and whether investors are attracted to the Mauritian destination due to possibility of treaty shopping. There is a positive and significant relationship between the two variables, suggesting that not only treaty abuse is a possibility in Mauritian treaties but also FDI flow in Mauritius is due to a possibility of treaty shopping. 
Table 3. Opinions on tax treaty abuse

\begin{tabular}{|c|c|c|c|}
\hline & & $\begin{array}{l}\text { There is no form of treaty } \\
\text { abuse in Mauritian tax treaties }\end{array}$ & $\begin{array}{l}\text { Investors are attracted by } \\
\text { possibility of treaty shopping }\end{array}$ \\
\hline $\begin{array}{l}\text { There is no form of treaty } \\
\text { abuse in Mauritian tax treaties }\end{array}$ & $\begin{array}{l}\text { Pearson } \\
\text { Correlation } \\
\text { Sig. }(2 \text { tailed }) \\
\text { N }\end{array}$ & $\begin{array}{l}1 \\
87\end{array}$ & $\begin{array}{l}.264 * \\
.014 \\
87\end{array}$ \\
\hline $\begin{array}{l}\text { Investors are attracted by } \\
\text { possibility of treaty shopping }\end{array}$ & $\begin{array}{l}\text { Pearson } \\
\text { Correlation } \\
\text { Sig. (2 tailed) } \\
\text { N }\end{array}$ & $\begin{array}{l}.264^{*} \\
.014 \\
87\end{array}$ & $\begin{array}{l}1 \\
87\end{array}$ \\
\hline
\end{tabular}

*. Correlation is significant at 5\% level (2 tailed)

Table 4. Correlation on treaty abuse

\begin{tabular}{|c|c|c|c|}
\hline & & $\begin{array}{l}\text { There is no form of } \\
\text { treaty abuse in } \\
\text { Mauritian tax treaties }\end{array}$ & $\begin{array}{l}\text { A major part of Mauritian FDI flow } \\
\text { between tax treaty partners come as a } \\
\text { form of 'round tripping' }\end{array}$ \\
\hline There is no form of treaty & Pearson Correlation & 1 &.-0.60 \\
\hline abuse in Mauritian tax & Sig. (2 tailed) & & .584 \\
\hline treaties & $\mathrm{N}$ & 87 & 87 \\
\hline A major part of Mauritian & Pearson Correlation & ..-0.60 & 1 \\
\hline FDI flow between tax & Sig. (2 tailed) & .584 & \\
\hline $\begin{array}{l}\text { treaty partners come as a } \\
\text { form of 'round tripping' }\end{array}$ & $\mathrm{N}$ & 87 & 87 \\
\hline
\end{tabular}

*. Correlation is significant at $5 \%$ level (2 tailed)

Table 4 shows the relationship between the perceptions of respondents on whether there is a form of treaty abuse in Mauritian tax treaties and whether a big proportion of Mauritian FDI flow between tax treaty partners are in a form of 'round tripping'. There is no significant relationship between the 2 variables, as suggested by a high significance level of .584. This suggests that despite respondents believe that there is a form of treaty abuse in Mauritian tax treaties, Mauritian FDI is not exposed to a money laundering tool like round tripping. Correlations presented in table 3 and 4 are variables which have been subject to high criticism in recent years. Destinations like Mauritius, Cayman Islands or Singapore have been linked with money laundering source of FDI through round tripping or treaty shopping. This study shows valuable information that its population believe that there might be a form of treaty shopping in Mauritian tax treaties but round tripping might not be as evident.

Hypothesis

When asked if imposing a CGT on a tax treaty affect FDI, $100 \%$ of respondents agreed positively. The same scenario occurred when respondents were asked if foreign investors, in general, prefer to invest in treaties offering low or no CGT. Interestingly, when respondents were asked if the non-levy of CGT is the main factor affecting FDI, the answers were shared between 'yes' and 'no'. This question was used to provide for a hypothesis whereby:

Ho: CGT is not the main determinant in attracting FDI

H1: CGT is the main determinant in attracting FDI

A one-sample test was used in SPSS 23 to test the hypothesis with a 2-tail test at a 5\% significance level.

Table 5. One-Sample Test

\begin{tabular}{lllllll}
\hline \multicolumn{9}{c}{ Test Value $=2$} & & & \\
\cline { 2 - 4 } & $\mathrm{t}$ & $\mathrm{df}$ & Sig. (2-tailed) & Mean Difference & Lower & Upper \\
\hline $\begin{array}{l}\text { Is the non-levy of CGT in tax } \\
\text { treaties the main factor } \\
\text { affecting FDI? }\end{array}$
\end{tabular}

Note: CI. Correlation is significant at $5 \%$ level (2 tailed)

The sample mean was 1.56 and at a 5\% significance level on a 2-tailed test, it is agreed that the non-levy of CGT in tax treaties does not represent the main factor affecting FDI. Hence, the alternative hypothesis is accepted at a $5 \%$ significance level. However, this factor is deemed to be an important determinant of FDI and further tests are carried out through the gravity model to measure its importance.

The following table shows the descriptive statistics of the panel data for the different factors analysed. The study 
period is 5 years (2010-2014). In total, there are 25 observations. Skewness has to be measured to find the asymmetry between a probability distribution of a random variable value's mean and the normal distribution. Kurtosis compares the normal distribution to the data and test whether data is peaked or flat. Skewness is 0 and Kurtosis is approximately 3 for a normal distribution.

Table 6. Descriptive statistics

\begin{tabular}{llllll}
\hline Variable & Observation & Mean & Std. Dev. & Min & Max \\
\hline LN Net FDI & 25 & 17.04381 & 1.334697 & 14.63428 & 18.95429 \\
LN per cap GDP & 25 & 9.109603 & .0862668 & 8.958296 & 9.211999 \\
MRU & & & & & 10.77 \\
LN per cap GDP & 25 & 9.2572 & 1.327954 & 7.24 & -.0589011 \\
trade partners & & & & & 2 \\
LN Distance & 25 & -.4100657 & .3807032 & -1.011426 & 2 \\
CGT & 25 & 1.44 & .5066228 & 1 & 1 \\
$\begin{array}{l}\text { Common } \\
\text { Language }\end{array}$ & 25 & 1.8 & .4082483 & & \\
\hline
\end{tabular}

From table 6, it can be seen that there are many factors which contribute to positively affect FDI. However, the further away is the distance between home and host country, the more it affects FDI. This is represented by negative mean value of approximately -0.41 .

\section{Correlation matrix of coefficients}

The correlation matrix of coefficients is used to measure correlations between independent variables.

Table 7. Correlation matrix of coefficients

\begin{tabular}{lllllll}
\hline $\boldsymbol{E}(\boldsymbol{V})$ & LnPCGDPi & LnPCGDPj & Ln Distance & Common Lang & CGT & Constant \\
\hline LnPCGDPi & 1.0000 & & & & & \\
LnPCGDPj & -0.1711 & 1.0000 & & & & \\
Ln Distance & 0.1276 & -0.7750 & 1.0000 & & \\
Common Lang & 0.2153 & -0.5953 & 0.5649 & 1.0000 & 1.0000 & \\
CGT & -0.3558 & 0.3580 & -0.2629 & -0.5490 & 0.3182 & 1.0000 \\
Constant & -0.9948 & 0.0789 & -0.0562 & -0.1863 & \\
\hline
\end{tabular}

Table 7 does not show any evidence of multi-collinearity problems among the independent variables. The highest value was between Ln Distance and Ln per capita GDP of Mauritius. Hence, all independent variables can be included in the regression model, based on the multicollinearity test.

\section{Regression Model}

Three models of regression were considered for this study: the Hausman Test, Wooldridge test for autocorrelation in panel data and Breusch-Pagan / Cook-Weisberg test for heteroscedasticity.

Table 8. Regression models

\begin{tabular}{llll}
\hline & Breusch-Pagan/Cook-Weisberg & Wooldridge Test & Hausman Test \\
\hline Prob. & 0.3909 & 0.6828 & 0.0000 \\
Ho & Accept & Do not reject & Accept \\
Conclusion & Heteroscedasticity is absent & $\begin{array}{l}\text { First-order autocorrelation is } \\
\text { absent }\end{array}$ & $\begin{array}{l}\text { REM is consistent and } \\
\text { efficient }\end{array}$ \\
\hline
\end{tabular}

Note: Tests follow a $5 \%$ significance level

The table shows the null hypothesis for Breusch-Pagan/Cook-Weisberg test is accepted and no form of heteroscedasticity is found. The Wooldridge test suggests that there is no first order autocorrelation. Finally, the Hausman test has accepted the null hypothesis and it is concluded that REM is a better measure than the FEM here. Hence, the REM test will be the most appropriate test to use. 


\section{Regression Results}

Table 9. Regression results

\begin{tabular}{|c|c|c|c|c|c|c|}
\hline Ln Net FDI & Coefficient & Standard & $\mathbf{t}$ & $\mathbf{P}>|\mathbf{t}|$ & \multicolumn{2}{|c|}{$95 \%$ confidence interval } \\
\hline $\begin{array}{l}\text { LN PC GDP } \\
\text { Home }\end{array}$ & -3.324251 & 3.076615 & -1.08 & 0.293 & -9.763681 & 3.115179 \\
\hline $\begin{array}{l}\text { LN PC GDP } \\
\text { Host }\end{array}$ & .7641128 & .3121449 & 2.45 & 0.024 & .1107861 & 1.41744 \\
\hline LN Distance & -2.827128 & 1.061111 & -2.66 & 0.015 & -5.048058 & -.6061983 \\
\hline Common Lang & -1.76984 & .8701177 & -2.03 & 0.056 & -3.591017 & .0513371 \\
\hline CGT & 1.42461 & .6168424 & 2.31 & 0.032 & .1335442 & 2.71567 \\
\hline cons & 40.22783 & 27.64073 & 1.46 & 0.162 & -17.62487 & 98.08054 \\
\hline
\end{tabular}

The regression analysis performed on the variables used in the gravity formula has given results. Most of the variables used have provided significant and positive results with the exception of Ln Per Capita GDP of Mauritius.

Using the REM, the following table is generated.

Table 10. Findings on hypothesis testing

\begin{tabular}{lllllll}
\hline Ln Net FDI & Coefficient & $\begin{array}{l}\text { Standard } \\
\text { error }\end{array}$ & $\mathbf{t}$ & $\mathbf{P}>|\mathbf{t}|$ & $\mathbf{9 5 \%} \mathbf{C I}$ & \\
\hline LN PC GDP & -3.324251 & 3.076615 & -1.08 & 0.280 & -9.354306 & 2.705804 \\
Home & & & & & \\
LN PC GDP & .7641128 & .3121449 & 2.45 & 0.014 & .1523201 & 1.375906 \\
Host & & & & & \\
LN Distance & -2.827128 & 1.061111 & -2.66 & 0.008 & -4.906867 & -.7473897 \\
Common Lang & -1.76984 & .8701177 & -2.03 & 0.042 & -3.475239 & -.0644408 \\
CGT & 1.42461 & .6168424 & 2.31 & 0.021 & .2156213 & 2.633599 \\
cons & 40.22783 & 27.64073 & 1.46 & 0.146 & -13.947 & 94.40266 \\
\hline
\end{tabular}

Note: CI. Correlation is significant at $5 \%$ level (2 tailed)

Hypothesis 1: Per Capita GDP of host country has positive and significant statistical impact on FDI.

H0: Per capita GDP of host country does not have any statistical impact on FDI

H1: Per capita GDP of host country has a positive significant statistical impact on FDI

With a $\mathrm{P}>|\mathrm{t}|$ value of 0.014 , there is some evidence to reject the null hypothesis that there is no linear relationship between FDI flow and Per Capita GDP of host country. The result shows that as GDP per capita of host country increases, FDI flow between that country and Mauritius will consequently increase. As GDP per capita of the host country increases by 1 unit, FDI flows between Mauritius and the host country will increase by .7641128 unit. This supports Artige \& Nicolini (2005) analysis that GDP per capita is one of the major determinants of FDI.

Hypothesis 1.1: Per Capita GDP of home country has positive and significant statistical impact on FDI.

H0: Per capita GDP of home country does not have any impact on FDI

H1: Per capita GDP of home country has a positive significant statistical impact on FDI

The $\mathrm{P}$ value 0.280 is much higher than the significance level of $5 \%$ and this suggests that if ever there is a relationship, it is the occurrence of coincidence. Hence, there is no significant evidence between FDI flows and Mauritian GDP per capita. Hence, the null hypothesis will be accepted.

$\mathrm{H} 2$ : Introducing CGT or news of future imposition of CGT has negative and significant statistical impact on FDI

This had been declared as the most important variable of this study. In fact, it was deemed that even with a news of probable imposition of CGT in a double tax treaty becomes known, FDI will decrease by a given value. P value of .021 suggests that there is a linear relationship between CGT and FDI. It is seen that not having any form of CGT and that there is no kind of news which report the likelihood of imposing a form of CGT will positively impact FDI by 1.42461 units.

This is consistent with Hartman (1994), (Grubert \& Mutti 1991), and Kemsley (1998) who argued that corporate taxes, including CGT have a negative and significant impact on FDI. However, the hypothesis is inconsistent with the findings of Swenson (1994) who showed a positive correlation between imposition of taxes and increase in FDI flows. The alternative hypothesis is accepted, where it is agreed that there is a significant and negative relationship between FDI and CGT.

H3: Distance between home and host country has negative and significant impact on FDI flows

$\mathrm{P}$ value of 0.008 suggests a linear relationship between distance and FDI flows. This study used 0.1 as proxy for 
$1000 \mathrm{~km}$ and it is suggested from the table that every $1000 \mathrm{~km}$ distance between two trading partners will affect FDI by -2.827128 . This idea is supported by Rey (1999) who evidenced that there is a high correlation between distance and trade between two countries. Hence the null hypothesis is rejected at a 5\% confidence interval.

H4: Inexistence of common language between host country and home country negatively and significantly impact on FDI flows.

H0: Inexistence of common language between host country and home country does not have any statistical impact on FDI

H1: Inexistence of common language between host country and home country negatively and significantly impact on FDI flows

$\mathrm{P}$ value of 0.042 suggests a linear relationship between common language and FDI. The absence of an official common language seems to negatively affect FDI by -1.76984 .

\section{Conclusion and Recommendations}

This study includes various factors affecting FDI in the context of Mauritius and its treaty partners. The study uses two research methods, both given 2 different sets of factors, excluding imposition or news of future imposition of FDI, to provide answers in 2 different angles. However, it is known from the literature that FDI is affected by many more variables, many of which were not included in this analysis. For example, (Hattari \& Rajan, 2009) had included several factors in their research and most of them have not been used in this study due to time constraint. This study also used a panel data consisting of 4 trading partners: India, Belgium, South Africa and China. However, chapter 2 shows that Mauritius has a tax network consisting of not less than 43 countries. A further study taking into consideration this vast amount of data can provide for more reliable analysis. Moreover, the panel data constitute of only 5 years from 2010-2014 due to availability of data from reliable sources. Future researchers can make use of a longer panel data and obtain data for more reliable analysis. As seen in this study there are various factors which statistically and significantly affect FDI between two trading countries. Some of these factors, such as trading country per capita GDP and distance, cannot be controlled by the home country- Mauritius. However, there are several factors which the local government and investors could use to attract FDI. It has been seen that corruption index score plays an important role in attracting FDI. Transparent public institutions, fair banking system and increasing roles of the private sector can be made available to upgrade the Mauritian corruption index vis-à-vis the rest of the world. Equally, it has been seen that countries investing in the education system to break language barriers could make it easier for foreign investors to invest in the country. Cultural affinities play a role and common language between trading countries make it easier for investment to flow between the countries. Lastly, it has been seen that CGT is a major determinant of attracting FDI into Mauritius. It is recommended that as far as possible, tax treaties which provide the right for Mauritius to tax capital gains should not be amended. This allows for a situation where CGT is not levied at all and it is an important determinant of FDI.

Finally, Mauritian authorities should also educate the population about the new concept of BEPS as it seems to worry investors, according to respondents. BEPS is a matter of concern for small insulate countries like Mauritius which highly rely on FDI for investment. Educating the population about the positives and drawbacks of such a project can help prepare the population for any future impact on FDI flows. This study aims to investigate the main factors affecting FDI in the context of Mauritian tax treaties. This study had also a secondary motive of finding whether CGT is the main determinant of FDI flows between Mauritius and its tax treaty partners. The imposition of CGT in Mauritius-China (2014), Mauritius-South-Africa (2014) and Mauritius-India (2016) tax treaties have had for reason treaty abuse by foreign investors. Respondents from the questionnaire survey also agreed that not only CGT is a main determinant of FDI but equally that there is a form of treaty abuse in Mauritian tax treaty. As it has been seen that CGT is indeed a main determinant of FDI flows between Mauritian tax treaty partners, it can be concluded that there currently exists a form of treaty abuse in Mauritius. Respondents have given valuable insight that despite there may exist forms of treaty shopping in Mauritius, they do not perceive Mauritius as a destination allowing 'round tripping' of FDI. The study has also provided insight about the possible negative effects of the OECD's BEPS project on Mauritian FDI. Most of the questioned population share the idea that BEPS will indeed negatively affect Mauritian FDI. However, BEPS is a new concept and can easily be misinterpreted before any real events occur on imposition.

Determinants such as distance between home and host country, host country per capita GDP and even common language seem to play a significant role in FDI flows between Mauritius and its tax treaty partners. This study has shown that cultural affinities also play an important role in FDI flows between countries. Mauritius is historically attached to China and India and this can provide a valid reason why FDI flows have been so massive in the past between the countries. However, this hypothesis could not be tested due to time factor and unavailability of suitable models. As a concluding note, it is difficult to find the primary determinant of FDI 
flowing between Mauritius and its treaty partners. However, main determinants can be generalised through use of tools like the Gravity Model, with availability of appropriate data.

\section{References}

Agarwal, J. P. (1980). Determinants of Foreign Direct Investment, A Survey. Weltwirtschaftliches Archiv, 739-773. https://doi.org/10.1007/BF02696547

An, Z. (2011). Taxation and foreign direct investment (FDI): empirical evidence from a quasi-experiment in China. International Tax and Public Finance October 2012, 19(5), 660-676.

Artige, L., \& Nicolini, R. (2005). Evidence on the Determinants of Foreign Direct Investment: The Case of Three European Regions. CREPP Working Paper 2006/07.

Barthel, F., Busse, F., \& Neumayer, M. (2009). The Impact of Double Taxation Treaties on Foreign Direct Investment: Evidence From Large Dyadic Panel Data. Contemporary Economic Policy (ISSN 1465-7287).

Benassy-Quere, A., Fontagne, L., \& Lahreche-Revil, A. (2003). Tax Competition and Foreign Direct Investment, CEPII. Working paper, No.17, 8-26.

Blonigen, B. (2005). A review of the Empirical Literature on FDI Determinants. Atlantic Economic Journal, 33, 383-403. https://doi.org/10.1007/s11293-005-2868-9

Braunschweig, A. (2014). Double Taxation Treaties' Impact on Intermediate Trade. Lund University, 5-38.

Brooks, D. H., Fan, E. X., \& Sumolong, L. R. (2003). Foreign Direct Investment in Developing Asia: Trends, Effects, and Likely Issues for the Forthcoming WTO Negotiations. ERD Working Paper No. 38. Manla, PH: Asian Development Bank. Oxford: Oxford University Press.

Cheng, L. K., \& Kwan, Y. K., (2000). What are The Determinants of the Location of Foreign Direct Investment? The Chinese Experience. Journal of International Economics, 51(1), 379-400. https://doi.org/10.1016/S0022-1996(99)00032-X

Cieslik, A., \& Ryan, M. (2004). Explaining Japanese Direct Investment Flows into an Enlarged Europe: A Comparison of Gravity and Economic Potential Models. Journal of the Japanese and International Economies, 18(1), 12-37. https://doi.org/10.1016/j.jjie.2003.09.009

Crespo, N., \& Fontoura, M. P. (2007). Determinant Factors of FDI Spillovers- What do We Really Know? World Development, 35(3), 410-425. https://doi.org/10.1016/j.worlddev.2006.04.001

Diamond, P., \& Mirrlees, J. (1971). Optimal Taxation and Public Production, I: Production Efficiency (II: Tax Rules). American Economic Review 61, March, 8-27.

Dimitropoulou, D., Burke, S., \& MC Cann, P. (2007). The Determinants of the Location of Foreign Direct Investment in UK Regions, Editorial Express. Applied Economics, 45(27), 3853-3862. https://doi.org/10.1080/00036846.2011.558482

Eicher, T., Helfman, L., \& Lenkoski, A. (2011). Robust FDI Determinants: Bayesian Model Averaging in the Presence of Selection Bias, University of Washington, Washington.

Gordon, H. (1990). Can Capital Income Taxes Survive In Open Economies? NBER working paper series, National Bureau of Economics Research, Working paper No. 3416, 1-23.

Groh, A. P., \& Wich, M. (2009). A Composite Measure to Determine a Host Country's Attractiveness for Foreign Direct Investment. University of Navarra Working Paper, Barcelona. https://doi.org/10.2139/ssrn.1550717

Grubert, H., \& Mutti, J. (1991). Taxes, Tariffs and Transfer Pricing in Multinational Corporate Decision Making. Review of Economic Studies, 73, 285-293. https://doi.org/10.2307/2109519

Hartman, D. G. (1994). Tax Policy and Foreign Direct Investment in the United States. National Tax Journal, 37(4), 475-488.

Hattari, R., \& Rajan, R. S. (2009). Understanding Bilateral FDI Flows in Developing Asia. Asian-Pacific Economic Literature, 23(2), 73-93. https://doi.org/10.1111/j.1467-8411.2009.01232.x

Hines, J. R. (1998). International Taxation And Multinational Activity. The University Of Chicago Press Working paper. Chicago and London, 39-72.

Itaki, M. (1991). A Critical Assessment of the Eclectic Theory of the Multinational Enterprise. Journal of International Business Studies, 25, 445-460. https://doi.org/10.1057/palgrave.jibs.8490310 
Jordaan, J. C. (2004), Foreign Direct Investment and Neighbouring Influences. (Unpublished doctoral thesis University of Pretoria.

Kemsley, D. (1998). The Effect of Taxes on Production Location. Journal of Accounting Research, 36, 321-341. https://doi.org/10.2307/2491480

Kim, M., Liu, A, Tuxhorn, K. L., Brown, T., \& Leblang, D. (2013). Lingua Mercatoria: Language and Foreign Direct Investment. International Studies Quarterly, 330-343.

Kinoshita, Y., \& Campos, N. (2002). The location determinants of foreign direct investment in transition economies. Institute of Social Science, University of Tokyo, Tokyo.

Kolstad, I., \& Villanger, E. (2004). How does social development affect FDI and domestic investment? Michelsen Institute CMI, Bergen.

Morisset, J. (2003). Does a country need a promotion agency to attract foreign direct investment? A Small Analytical Model Applied to 58 Countries, The World Bank, Policy Research Working Papers, No. 3-28, Washington, D.C.

Noorbakhsh, F., Palom, A., \& Youssef, A. (2001). Human Capital and FDI Inflows to Developing Countries: New Empirical Evidence. World Development, 29(9), 1593-1610. https://doi.org/10.1016/S0305-750X(01)00054-7

Ohno, T. (2010). Empirical Analysis of International Tax Treaties and Foreign Direct Investment. Economist, Policy Research Institute, Ministry of Finance of Japan.

Parry, T. G. (1985). Internalization as a General Theory of Foreign Investment: A Critique. Weltwirtschaftliches Archiv, 121(3), Springer, 564-569. https://doi.org/10.1007/BF02708193

PETRI, P. (2012). The Determinants of Bilateral FDI: Is Asia Different? Journal of Asian Economics, 23, 201-209. https://doi.org/10.1016/j.asieco.2011.01.003

Portes, M., \& Rey, H. (2000). Financial integration and asset returns, European Economic Review, 44, 1327-1350. https://doi.org/10.1016/S0014-2921(00)00036-2

Razin, A., \& Sadka, E. (2007). Foreign Direct Investment: Analysis of Aggregate Flows, Princeton University Press, chapter 4.

Rios-Morales, R., \& Brennan, L. (2007). Ireland's Foreign Direct Investment Competitive Advantage and Japanese Outward Foreign Direct Investment. Asia Pacific Business Review, 13(2), 201-231. https://doi.org/10.1080/13602380601133219

Sithanen, R. (2015). An Assessment Of The Consequences And Implications Of The Recent Protocol On The DTAA Between India And Mauritius On The Global Business Sector And The National Economy.

Sornarajah, M. (2015). The International Law on Foreign Investment" Cambridge University Press, Cambridge, 328-331.

Swenson, D. L. (1994). The Impact of U. S. Tax Reform on Foreign Direct Investment in the United States, Journal of Public Economics, 54, 243-266. https://doi.org/10.1016/0047-2727(94)90062-0

Tinbergen, J. (1962). Shaping the world economy: suggestions for an international economic policy. The Twentieth Century Fund, New York.

Wei, S. J., \& Smarzynsk, B. (2009). Corruption and composition of Foreign Direct Investment: Firm level evidence. National Bureau of Economic Research.

Wheeler, D., \& Mody, A. (1992). International Investment Location Decisions: The Case of US Firms, Journal of International Economics, 33, 57-76. https://doi.org/10.1016/0022-1996(92)90050-T

Wilson, J. D. (1991). Tax Competition with interregional differences in factor endowments, Regional Science and Urban Economics, 21(3), 423-451. https://doi.org/10.1016/0166-0462(91)90066-V

Wooldridge, J. (2002). Econometric Analysis of Cross Section and Panel Data, MIT Press.

\section{Copyrights}

Copyright for this article is retained by the author(s), with first publication rights granted to the journal.

This is an open-access article distributed under the terms and conditions of the Creative Commons Attribution license (http://creativecommons.org/licenses/by/4.0/). 